\title{
The Effect of Bio, Organic and Mineral Fertilizations on the Activity of the Urease, L-Glutaminase and L-Aspartase Enzymes in the Soil
}

\author{
Luma S. Al-Taweel ${ }^{1} \&$ Naseer Jawad Kazim $^{1}$ \\ ${ }^{1}$ Department Sciences of soil and water Resources, College of Agriculture, University of AL-Qadisiyah, Iraq \\ Correspondence: Luma S. Al-Taweel, Department Sciences of soil and water Resources, College of Agriculture, \\ University of AL-Qadisiyah, Iraq. E-mail: Luma.altawee@@qu.edu.iq, nasir.jawad.z.n@gmail.com
}

Received: July 17, 2019; Accepted: November 23, 2019; Published: November 24, 2020

\begin{abstract}
The study aimed to investigate the effect of the application of various sources of fertilizers on the activity of urease, L-glutaminase, and L-aspartase enzymes in the rhizosphere and bulk soils. Pots experiment was carried out in the wire canopy in one of the fields affiliated to the Faculty of Agriculture - the University of Qadisiyah for the summer season 2018 in soil with a silty loam texture. Seeds of mung bean crops were cultivated of a local variety (Khedrawi). The treatments of the study were two levels of nitrogenous mineral fertilizer (urea) $\left(\mathrm{M}_{1}\right.$ and $\left.\mathrm{M}_{2}\right)(20$ and 40) kg.N.h $\mathrm{h}^{-1}$, respectively, a single level of organic fertilizer (poultry waste) (10 tons $\left.\mathrm{h}^{-1}\right)$, a single level of biofertilizer with Pseudomonas fluorescens bacteria, the control, and their interactions. The experiment was carried out according to Completely Randomized Design (C.R.D) with six replications. Means were compared according to the (L.S.D) test at the probability level $(\alpha=0.05)$. The efficiency of urase, L-clotamene, and L-aspartase in the soil of the root zoon and bulk soil were estimated for all study parameters 30 days after planting. These measurements were done once again for some characteristics of vegetative and root growth after 60 days of planting.

The bio-fertilizer treatment (B) resulted in the highest increase in the efficiency of the urease enzyme and Laspartase for 30 days of cultivation compared to the control treatment that recorded the least value of the enzyme activity average (45.22 and 42.54) $\mu \mathrm{g} \mathrm{N}-\mathrm{NH}_{4}{ }^{+} \cdot \mathrm{g}^{-1}$ soil. $2 \mathrm{~h}^{-1}$, respectively, for the rhizosphere and bulk soils. These

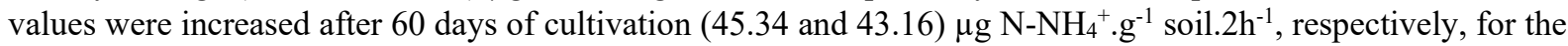
rhizosphere and bulk soils. This treatment achieves the highest increase in the activity of L-enzymes $(25.89$ and 24.72) $\mu \mathrm{g} \mathrm{N}-\mathrm{NH}_{4}{ }^{+} . \mathrm{g}^{-1}$ soil. $2 \mathrm{~h}^{-1}$, respectively, for the region of the rhizosphere and beyond. It increased after 60 days of cultivation (26.23 and 25.06) $\mu \mathrm{g} \mathrm{N}-\mathrm{NH}_{4}{ }^{+} \cdot \mathrm{g}^{-1}$ soil. $2 \mathrm{~h}^{-1}$, respectively, for the region of the rhizosphere and bulk soils. The treatment of poultry wastes $(\mathrm{O})$ resulted in the highest increase in the value of the activity of the Lclotamines enzyme in the rhizosphere and bulk soils for a period of 30 days from planting (43.47 and 57.39) $\mu \mathrm{g}$ $\mathrm{N}-\mathrm{NH}_{4}{ }^{+} \cdot \mathrm{g}^{-1}$ soil. $2 \mathrm{~h}^{-1}$, respectively. Its activity values then increased after 60 days of cultivation, reaching (44.33 and 40.43) $\mu \mathrm{g} \mathrm{N}-\mathrm{NH}_{4}{ }^{+} \cdot \mathrm{g}^{-1}$ soil. $^{2} \mathrm{~h}^{-1}$, respectively.

The overlap treatment between poultry residues and biofertilizers $(\mathrm{OB})$ achieved the highest increase in the activity value for the urase enzyme, L-clotamines and L-aspartase in root zoon soil and distant soil for 30 days of cultivation (54.47, 46.84 and $28.28 \mu \mathrm{g} \mathrm{N}-\mathrm{NH}_{4}{ }^{+} \cdot \mathrm{g}^{-1}$ soil. $2 \mathrm{~h}^{-1}$, respectively, for the rhizosphere and $(49.14,37.81$ and 23.94$) \mu \mathrm{g}$ $\mathrm{N}-\mathrm{NH}_{4}{ }^{+} . \mathrm{g}^{-1}$ soil. $2 \mathrm{~h}^{-1}$, respectively. The activity of enzymes then increased after 60 days of cultivation $(54.56,47.69$ and 28.62) $\mu \mathrm{g} \mathrm{N}-\mathrm{NH}_{4}{ }^{+} . \mathrm{g}^{-1}$ soil. $2 \mathrm{~h}^{-1}$, respectively, for the rhizosphere $\left(49.23,38.67\right.$ and 24.18) $\mu \mathrm{g} \mathrm{N}-\mathrm{NH}_{4}{ }^{+} . \mathrm{g}^{-1}$ soil. $2 \mathrm{~h}^{-1}$, respectively, for the bulk soil. The combination treatments between poultry residues, bio-fertilizer, and urea at level II $\left(\mathrm{OBM}_{2}\right)$ achieved the highest increase in the activity values for urease enzyme, L-clotamines and L-aspartase in root zoon soil and bulk soil for 30 days of cultivation $\left(58.46,48.58\right.$ and 30.40) $\mu \mathrm{g} \mathrm{N}-\mathrm{NH}_{4}{ }^{+} . \mathrm{g}^{-1}$ soil. $2 \mathrm{~h}^{-1}$, respectively for the rhizosphere, and $\left(54.13,46.30\right.$ and 27.62) $\mu \mathrm{g} \mathrm{N}-\mathrm{NH}_{4}{ }^{+} \cdot \mathrm{g}^{-1}$ soil $2 \mathrm{~h}^{-1}$, respectively, for the bulk soil. The activity of enzymes then increased 60 days after planting $\left(58.55,49.44\right.$ and 30.74) $\mu \mathrm{g} \mathrm{N}-\mathrm{NH}_{4}{ }^{+} \cdot \mathrm{g}^{-}$ ${ }^{1}$ soil. $2 \mathrm{~h}^{-1}$, respectively, for the rhizosphere $\left(54.22,47.15\right.$ and 27.96) $\mu \mathrm{g} \mathrm{N}-\mathrm{NH}_{4}{ }^{+} \cdot \mathrm{g}^{-1}$ soil. $2 \mathrm{~h}^{-1}$, respectively, outside the rhizosphere.
\end{abstract}

Keywords: urease enzyme, L-clotamines, L-aspartase, bio-fertilizers, mung bean

\section{Introduction}

Nitrogen is one of the most important nutrients in fertilization programs because plants need it in higher quantities than other nutrients (E-Aziz and El-Ashry, 2009). This element is involved in building the chlorophyll molecule, 
building proteins, enzymes, cellular membranes, cell division and elongation, and the formation of new cells as well as increasing plant tolerance to extreme environmental conditions (Barker and Bryson, 2007). Urea fertilizer is the most widely used fertilizer of nitrogen in the soil and the most used in the world due to its high nitrogen content (46\%) and low production costs (Selim et al., 2010). The area of the root zoon (Rhizosphere) is known as the area of vital activity of plant roots, as recent studies have shown that this region is a place for the occurrence of the most biological interactions between microorganisms and the soil ecosystem, as these activities decrease outside this region (Bulk Soil) (Hinsinger et al., 2006 ; Khaeim et al., 2019). This area contains a large number of microorganisms, including fungi, bacteria, and radial fungi. Many factors affect the activity of these neighborhoods, such as soil type, temperature, and plant age. The biomass in the rhizosphere affects the mineralization process of the elements. The microorganisms have two primary roles in this field, as they enter into the nutrient cycles in the soil, and they also interfere with all endemic microorganisms, including plants. The root zone contains root secretions that encourage the growth of microorganisms as they are a source of energy and carbon necessary for their growth. Among these secretions are organic acids, amino acids, carbohydrates, and some inorganic compounds such as $\mathrm{CO}_{2}$ and inorganic ions. Root secretions also contain enzymes that are released to the root region (Shulka and Varma, 2011; Khaeim et al., 2019).

Soil enzymes play a fundamental role in the processes of decomposition of organic matter in the soil system and are important in stimulating many of the necessary interactions in the continuation of the life of soil microorganisms and the stability of soil construction (Sinsabaugh et al., 1991 ; Dick et al., 1994; Al-Taweel and Abo-Tabikh, 2019 ). It is well known that all biochemical reactions are carried out with the help of enzymes, and many factors affect the activity of enzymes and groups of microorganisms in the soil and thus affect the availability of the elements (Colombo et al., 2002) mentioned that when the organic matter is available, the activity of soil enzymes increases and that the enzymes contribute to stimulating a large number of necessary and important interactions of the biological processes of the soil microorganisms that degrade the organic residues. The important role of the organic matter in the soil comes through the products of its decomposition. The application animal or plant waste to the soil would subject to attack by microorganisms that work to analyze these materials.

The application of organic waste to the soil improves its physical, chemical, and fertile properties, as well as its biological activity, and contributes to increasing agricultural production by supplying the plant with the nutrients necessary for its growth (Abu Niqtah, 2004). Biofertilizer is described as a product that contains natural biological microorganisms that are free of chemical compounds that settle plant roots or enter plant tissues and encourage and stimulate their growth through their ability to supply nutrients and resist them to certain environmental conditions (Lakshmana, 2000). Bio-fertilization helps in the availability of nutrients with different mechanisms, including reducing the degree of interaction of the soil $(\mathrm{pH})$ through the secretion of organic acids and their production of phytohormones and their production of antibiotics to protect themselves and protect the plant from bacterial and fungal diseases (Vessey, 2003).

Biofertilizers are not like mineral fertilizers that applied nutrients to the soil only, but also help in preparing nutrients through the various natural processes in the soil and increase the plant's susceptibility to fighting diseases. The main goal of adding mineral fertilizers is to equip the plant with the appropriate quantities of nutrients in a balanced and rapid manner to compensate for the shortage in the soil of these elements. To obtain the highest production, it requires a balanced amount of these elements, according to the need of the crop and what is readily available in the soil. The study aimed to investigate the activity of the enzyme of urease, L-clotamene, and Laspartase in the soil of the root zoon and bulk soils.

\section{Methods and Materials}

\subsection{Site Work of the Experiment}

The experiment was done in one of the greenhouses of the College of the Agriculture - University of Al-Qadisiyah. Soil samples were randomly taken from the surface layer at a depth of $(0-30 \mathrm{~cm})$, air-dried. Samples were crushed and sifted with a sieve with a diameter of (2) $\mathrm{mm}$. These soil samples were mixed well to obtain homogeneity, and some chemical, physical, and biological tests were conducted before planting, Table (1). 
Table 1. Chemical and physical properties of the soil before planting.

\begin{tabular}{|c|c|c|c|c|}
\hline \multicolumn{2}{|l|}{ Trait } & Value & Unit & Reference \\
\hline \multicolumn{2}{|c|}{ Reaction Degree $(\mathrm{pH})(1: 1)$} & 7.60 & ------------------- & \multirow[b]{2}{*}{ Black, (1965) } \\
\hline \multicolumn{2}{|c|}{ Electrical Conductivity (EC) $(1: 1)$} & 3.42 & DesiSmens.M $^{-1}$ & \\
\hline \multicolumn{2}{|c|}{ Cation exchange capacity (CEC) } & 23.73 & Cml.charge. $\mathrm{kg}^{-1}$.soil & Papanicolaou \\
\hline \multicolumn{2}{|l|}{ Organic carbon } & 0.84 & \multirow{3}{*}{ g. $\mathrm{kg}^{-1}$} & \multirow{3}{*}{ Black, (1965) } \\
\hline \multicolumn{2}{|l|}{ Organic matter } & 1.46 & & \\
\hline \multicolumn{2}{|l|}{ Total nitrogen } & 0.39 & & \\
\hline \multirow{7}{*}{ Dissolved ions } & $\mathrm{Ca}^{2+}$ & 25.45 & \multirow{7}{*}{ Cml.charge. $\mathrm{L}^{-1}$} & \multirow{7}{*}{ Black, (1965) } \\
\hline & $\mathrm{Mg}^{2+}$ & 13.44 & & \\
\hline & $\mathrm{Na}^{1+}$ & 40.58 & & \\
\hline & $\mathrm{SO}_{4}^{2-}$ & 17.95 & & \\
\hline & $\mathrm{HCO}_{3}{ }^{1-}$ & 16.8 & & \\
\hline & $\mathrm{CO}_{3}^{2-}$ & Nill & & \\
\hline & $\mathrm{Cl}^{-}$ & 41.56 & & \\
\hline \multicolumn{2}{|c|}{ +available nitrogen } & 16.30 & \multirow[t]{2}{*}{$\mathrm{Mg} \mathrm{kg}^{-1}$ soil } & Page et al., (1982) \\
\hline \multicolumn{2}{|c|}{ Available potassium } & 164.40 & & \multirow{4}{*}{ Black, (1965) } \\
\hline \multicolumn{2}{|l|}{ Total bacteria } & $13.21 * 10^{6}$ & \multirow{2}{*}{ CFU.g $\mathrm{g}^{-1}$ dry soil } & \\
\hline \multicolumn{2}{|l|}{ Total fungi } & $1.4 * 10^{3}$ & & \\
\hline \multicolumn{2}{|l|}{ Bulk Density } & 1.36 & & \\
\hline \multirow[t]{3}{*}{ Soil Separators } & Sand & 270 & \multirow{3}{*}{ g. $\mathrm{kg}^{-1}$} & \multirow{4}{*}{ Black, (1965) } \\
\hline & Loam & 540 & & \\
\hline & clay & 190 & & \\
\hline \multicolumn{2}{|l|}{ Texture type } & \multicolumn{2}{|l|}{ Silt Loam } & \\
\hline \multicolumn{2}{|l|}{ urease enzyme } & \multicolumn{2}{|l|}{20.50} & \multirow{3}{*}{$\mu \mathrm{g} \mathrm{N}-\mathrm{NH}_{4}{ }^{+} \mathrm{g}^{-1}$ soil. $2 \mathrm{~h}^{-2}$} \\
\hline \multicolumn{2}{|c|}{ L-clotamines enzyme } & \multicolumn{2}{|l|}{13.32} & \\
\hline L-aspartase enz & & 11.54 & & \\
\hline
\end{tabular}

\subsection{Experimental Design of the Experiment}

This a simple one-way experience following a Completely Randomized Design (CRD). Four experimental treatments and six replicates were placed. The number of experimental units group up to (72) units.

\subsection{Experimental Treatments}

The experiment included the following treatments: Two levels of nitrogenous fertilizer (urea) $\left(\mathrm{M}_{1}\right)$ the application of (20) kg.N.h ${ }^{-1}$ (50\% of fertilizer recommendation), and $\left(\mathrm{M}_{2}\right)$ the application of $(40) \mathrm{kg} . \mathrm{N} \cdot \mathrm{h}^{-1}(100 \%$ of fertilizer recommendation). It included also a single level of organic fertilizer (poultry waste) $(\mathrm{O})$, the application of (10) ton. $\mathrm{h}^{-1}$, and a single level of bio-fertilizer Pseudomonas fluorescens (B) Pseudomonas fluorescens contamination (10) kg.bio-fertilizer. $\mathrm{kg}^{-1}$.seeds in addition to the control treatment.

Table 2. Some chemical and physical properties of the poultry wastes.

\begin{tabular}{lcc}
\hline \multicolumn{1}{c}{ property } & Unit & Value \\
\hline $\mathrm{pH}$ & --- & 6.4 \\
Organic matter & $\%$ & 65.0 \\
Total nitrogen & $\%$ & 4.2 \\
$\mathrm{C} / \mathrm{N}$ & $\%$ & 9.0 \\
Phosphorus $\left(\mathrm{P}_{2} \mathrm{O}_{5}\right)$ & $\%$ & 3.0 \\
Potassium $\left(\mathrm{K}_{2} \mathrm{O}\right)$ & $\%$ & 2.8 \\
\hline
\end{tabular}

\subsection{Pots Experiment}

Pots sized of (20) $\mathrm{kg}$ were used in this study. They intended for planting were filled with soil after the soil was mixed well for homogenization and then passed through a sieve with a diameter of (4) mm holes before filling with pots. Local variety (Khedrawi) of mung bean seed (Vigna radiate.L) obtained from the Seed Inspection and 
Certification Department in Al-Diwaniyah Governorate at a rate of (6) seeds per pot. The seedlings rugged out to (3) plants per pot a week after germination.

This study was conducted to study the effect of the bacterial bio-fertilizer with Pseudomonas fluorescens obtained from the Agricultural Research Center in Zafaraniah and organic (poultry waste) and mineral (urea) and their combination on the activity of the enzyme of urease, L-clotamene and L-aspartase in the soil of the root zone (rhizosphere) and bulk soils of the mung bean crop. Seeds were sterilized for biological fertilization treatments using (1)\% sodium hypochlorite for five minutes, then the seeds were washed with distilled water several times to remove the sterile material from them. The inoculated with Pseudomonas fluorescens carrying fertilizer (10) g. $\mathrm{kg}^{-}$ ${ }^{1}$.seed bio-fertilizer using (10) \% Arabic gum (was prepared by adding (10) g per (100) ml distilled water). This runs into autoclave striation under $(121)^{\circ} \mathrm{C}$ and pressure of (15) bar for an hour.

The Arabic gum is left to cool and then contaminated with Pseudomonas fluorescens and mung bean seeds and left for an hour. Poultry waste was applied at the level of (10) tons. $\mathrm{h}^{-1}$ and urea were applied at two levels (20 and 40) $\mathrm{kg} . \mathrm{N} . \mathrm{h}^{-1}$ twice, the first at the planting date and the second after (20) days of the first application. Triple superphosphate fertilizer was applied once at planting date according to the fertilizer recommendation $(80) \mathrm{kg} \cdot \mathrm{h}^{-1}$, and the application of potassium fertilizer in form of potassium sulfate in two batches with urea according to fertilizer recommendation (40) $\mathrm{kg} \cdot \mathrm{h}^{-1}$.

Table 3. The distribution of the experimental treatments and their symbols.

\begin{tabular}{|c|c|}
\hline TS & The application \\
\hline Cont. & No application \\
\hline $\mathrm{O}$ & 10 tons $^{-h^{-1}}$ compost (poultry waste) \\
\hline M1 & Mineral fertilizer (urea) (50\% of fertilizer recommendation) $20 \mathrm{~kg} . \mathrm{N} . \mathrm{h}^{-1}$ \\
\hline M2 & Mineral fertilizer (urea) ( $100 \%$ of fertilizer recommendation) 40 kg.N.h ${ }^{-1}$ \\
\hline B & bio-fertilizer Pseudomonas fluorescens \\
\hline OM1 & $\begin{array}{l}\text { Mineral fertilizer (urea) }(50 \% \text { of fertilizer recommendation) }+ \text { organic fertilizer (poultry waste) } 20 \\
\mathrm{kgNh}^{-1}+10 \text { tons. } \mathrm{h}^{-1}\end{array}$ \\
\hline OM2 & $\begin{array}{l}\text { Mineral fertilizer (urea) }(100 \% \text { of the fertilizer recommendation) + organic fertilizer (poultry waste) } \\
40 \mathrm{~N} \cdot \mathrm{h}^{-1}+10 \text { tons. } \mathrm{h}^{-1}\end{array}$ \\
\hline OB & 10 tons. $\mathrm{h}^{-1}$ Organic Fertilizer (Poultry Waste) + Pseudomonas fluorescens \\
\hline BM1 & Mineral fertilizer (urea) (50\% of fertilizer recommendation) $20 \mathrm{~kg} \cdot \mathrm{N} \cdot \mathrm{h}^{-1}+$ Pseudomonas fluorescens \\
\hline BM2 & $\begin{array}{l}\text { Mineral fertilizer (urea) (100\% of the fertilizer recommendation) } 40 \mathrm{~kg} . \mathrm{N} \cdot \mathrm{h}^{-1}+\text { Pseudomonas } \\
\text { fluorescens }\end{array}$ \\
\hline OBM1 & $\begin{array}{l}\text { Mineral fertilizer (urea) }\left(50 \% \text { of fertilizer recommendation) } 20 \mathrm{~kg} \cdot \mathrm{N} \cdot \mathrm{h}^{-1}+\text { organic fertilizer (poultry }\right. \\
\text { waste) } 10 \text { tons. }^{-1}+\text { Pseudomonas fluorescens }\end{array}$ \\
\hline OBM2 & $\begin{array}{l}\text { Mineral fertilizer (urea) }\left(50 \% \text { of fertilizer recommendation) } 40 \mathrm{~kg} \cdot \mathrm{N} \cdot \mathrm{h}^{-1}+\text { organic fertilizer (poultry }\right. \\
\text { waste) } 10 \text { tons. }^{-1}+\text { Pseudomonas fluorescens }\end{array}$ \\
\hline
\end{tabular}

\subsection{Laboratory Examinations}

Samples of soil from the rhizosphere and bulk soils (30 and 60) days after planting the crop were taken for examinations. These samples were stored in plastic containers in the refrigerator for the analysis of organic carbon and total nitrogen. Chemical, physical and biological tests were conducted before planting, which was randomly taken at a depth of (0-30) cm.

The physical tests were assayed according to the methods mentioned in (Black, 1965). The soil separators were estimated by the absorbent method, and bulk density was estimated using a cylindrical ring method (Core sample).

The Chemical tests were assayed according to the methods mentioned in (Black, 1965). The degree of soil reaction $(\mathrm{pH})$ was assayed in soil extract of soil: water (1: 1) using $\mathrm{pH}$ meter. The electrical conductivity (EC) was estimated in soil extract: water (1:1) using an EC- meter. The cation exchange capacity (CEC) was estimated by selling the soil with $\mathrm{CaCl}_{2}$ (1.0) standard solution and then displacing with a standard (1.0) sodium nitrate solution according to the Papanicolao method (1976). The Calcium carbonate $\mathrm{CaCO}_{3}$ content was assayed by calculating the loss in $\mathrm{CO}_{2}$ after treating the soil with (3.0) hydrochloric acid.

The positive and negative dissolved ions were estimated in an extract (1:1) according to the methods mentioned in (Black, 1965) as follows: Calcium $\left(\mathrm{Ca}^{2+}\right)$ and magnesium $\left(\mathrm{Mg}^{2+}\right)$ were estimated by dissolving with a solution of fersnite $\left(\mathrm{Na}_{2}\right.$-EDTA). Sodium $\left(\mathrm{Na}^{+}\right)$and potassium $\left(\mathrm{K}^{+1}\right)$ were assayed using the Flame photometer. The 
Carbonates and bicarbonate $\left(\mathrm{HCO}^{-}\right)$were assayed by leaching with standard sulfuric acid 0.01 . The chloride $\left(\mathrm{Cl}^{-}\right)$ was assayed by the titrations with silver nitrate $\left(\mathrm{AgNO}_{3}\right)$ of $(0.005)$ standard. Soil sulfate $\left(\mathrm{SO}_{4}^{-2}\right)$ was assayed using sedimentation with acetone.

The organic matter was assayed by oxidation with a standard (1.0) standard potassium chromate solution using concentrated sulfuric acid and the correction with ammonia ferrous sulfate, using diphenylamine according to the Weakley - Black method mentioned in (Black, 1965). The organic matter of the rhizosphere and bulk soils were assayed by oxidation with a standard (1.0) dipotassium chromate solution using concentrated sulfuric acid and the correction with ammonia ferrous sulfate using the Diphenylamine reagent according to the Weakley - Black method contained in (Black, 1965). Total nitrogen contents in the rhizosphere and bulk soils were assayed by digesting the soil sample with concentrated sulfuric acid and using a micro-Kjeldahl steam distillation apparatus in the estimation according to (Bremner's, 1965) method mentioned in (Black, 1965).

Phosphorous availability in the rhizosphere and bulk soils were assayed by extracting it from sodium bicarbonate (0.5) molar and developed the blue color using ammonium molybdate and ascorbic acid. Then the available phosphorus was estimated with the spectrophotometer at (882) nm wavelength, according to the method described in (Page et al., 1982). Potassium availability in the rhizosphere and bulk soils were measured by extracting it using standard (1.0) \% ammonium acetate. The potassium content is measured using a flame photometer according to the method mentioned in (Black, 1965).

Decimal diluted solutions from $\left(10^{-1}\right.$ to $\left.10^{-6}\right)$, the diluted solutions of apprehensions $\left(10^{-5}\right.$ and $\left.10^{-6}\right)$ to grow bacteria using the nutrient agar medium were done. To counting the fungi, pancakes $\left(10^{-3}\right.$ and $\left.10^{-4}\right)$ using the Martin medium as reported. In (Black, 1965). Biomass carbon and released carbon dioxide were measured in the rhizosphere and bulk soils of the mung bean crop. The amount of carbon dioxide was measured according to the Stotzoky method described in (Black, 1965).

\subsection{Laboratory Experiments}

Soil samples were taken from the area of the root zoon and bulk soil 30 and 60 days after planting the crop. The samples were saved in plastic containers in the refrigerator to perform the biomass analyzes. Samples were also stored in the freezer until the estimates for the enzymatic activity were made, which included the following:

\subsubsection{The Activity of Urease Enzymes Assay}

The activity of urease enzyme, L-clotamene, L-aspartase in the soil of the rhizosphere and bulk soil were assayed for the 30 and 60 days of cultivation according to the following methods:

\subsubsection{Urease Enzyme Assay}

The activity of urease was assayed according to (Tabatabai and Bremner, 1972) method by incubating (5) gm of root and distant ocean soil in a (50) $\mathrm{ml}$ vial of volume with (0.2) $\mathrm{ml}$ of staining and $9 \mathrm{ml}$ of Tris (hydroxyl methyl aminomethane) solution with $(\mathrm{pH}=9)$, and (1) $\mathrm{ml}$ of urea solution is 0.2 molar as a subject at $(37)^{\circ} \mathrm{C}$ for two hours. After that (35) $\mathrm{mL}$ of potassium chloride solution (2.5) molar silver sulfate ppm (100) was applied as an inhibitor. The volume was completed to $50 \mathrm{ml}$ of the same solution. Ammonium nitrogen resulting from enzyme activity was estimated using the Micro-Kjeldahl steam distillation device according to the Bremner method contained in (Black, 1965) and using magnesium oxide and boric acid.

\subsubsection{L-Clotamene Enzyme Assay}

The activity of L-clotamines according to the (Frankenberger and Tabataba, 1991) was assayed by incubating (5) $\mathrm{g}$ of soil in a (50) $\mathrm{mL}$ volumetric flask with (0.2) $\mathrm{ml}$ of staining and $9 \mathrm{ml}$ of THAM buffer $\mathrm{pH}=(10)$ and (1) $\mathrm{ml}$ of L.glutamine (0.5) molar solution as a substance. After that, it was subjected to a temperature of $37^{\circ} \mathrm{C}$ for two hours. After incubation, (35) $\mathrm{mL}$ of (2.5) M molar solution - (100) PPM silver sulfate as an inhibitor was applied and the volume completed to (50) $\mathrm{mL}$ of the same solution. Ammonium nitrogen, which is a guide to the enzyme activity of the Micro-Kjeldahl apparatus, was estimated according to the Bremner method described in (Black, 1965).

\subsubsection{L-Aspartase Enzyme Assay}

The activity of the L-aspartase enzyme was assayed according to the Senwo and Tabatabai method (1996) by incubating (5) $\mathrm{g}$ of soil in a (50) $\mathrm{mL}$ volumetric flask with (0.2) $\mathrm{ml}$ of staining and (9) $\mathrm{ml}$ of THAM buffer $\mathrm{pH}=$ (8.5) and (1) $\mathrm{ml}$ of L-aspartic acid (2) molar as a subject at $37^{\circ} \mathrm{C}$ for 24 hours. Thereafter, add (35) $\mathrm{mL}$ of (2.5) $\mathrm{M}$ molarity solution - $100 \mathrm{ppm}$ silver sulfate as an inhibitor. The volume was completed to (50) $\mathrm{mL}$ of the same solution, then estimate the ammonium nitrogen, which is a guide to the enzyme activity of the Micro-Kjeldahl according to the Bremner method described in Black (1965). 


\section{Results and Discussion}

3.1 The Effect of the Biofertilizer (Pseudomonas Fluorescens), Poultry Wastes, and Urea on the Activity of Urease Enzyme ( $\mu \mathrm{g} \mathrm{N}-\mathrm{NH}_{4}^{+} \cdot \mathrm{g}^{-1}$ soil. $2 \mathrm{~h}^{-1}$ ) in and Outside the Rhizosphere of the Mung Bean after 30 and 60 Days of Cultivation

\subsubsection{The Activity of Urease Enzyme ( $\mu \mathrm{g} \mathrm{N}-\mathrm{NH}_{4}{ }^{+} . \mathrm{g}^{-1}$ soil. $\left.2 \mathrm{~h}^{-1}\right) 30$ Days after Planting}

The results presented in Table (4) show the effect of the application of poultry waste, urea, and bacterial fertilizer on the activity of the urease enzyme after (30) days of planting. The treatment of bio-fertilizer (B) Pseudomonas fluorescens recorded the highest significant increase in the activity value of urease enzyme for the rhizosphere regions and bulk soil (45.22 and 42.54) $\mu \mathrm{g} \mathrm{N}-\mathrm{NH}_{4}{ }^{+} \cdot \mathrm{g}^{-1}$ soil. $^{-1} \mathrm{~h}^{-1}$, respectively, compared to the comparison treatment that made the least value for urease enzyme activity was recorded (23.67 and 21.57) $\mu \mathrm{g} \mathrm{N}-\mathrm{NH}_{4}{ }^{+} . \mathrm{g}^{-1}$ soil. $2 \mathrm{~h}^{-1}$. The reason for the increase is because Pseudomonas fluorescens produces many enzymes, including the urease enzyme. Also, the increase in the microbial community means increasing the secretions of the microorganisms (Yoshimune, 2010).

Mittal et al. (2008) explained that the application of Pseudomonas fluorescens increased the average nitrogen in the rhizosphere. It indirectly affects the biological stimulation of nitrogen-fixing biota present in the soil, which increases the nitrogen availability that is necessary to stimulate the activity of the urease enzyme.

The treatment of poultry waste $(\mathrm{O})$ achieved a significant increase in the activity of urease in the rhizosphere and outside it (44.64 and 39.29) $\mu \mathrm{g} \mathrm{N}-\mathrm{NH}_{4}{ }^{+} \cdot \mathrm{g}^{-1}$ soil. $2 \mathrm{~h}^{-1}$, respectively, compared to the comparison treatment. Bergstrom et al. (1998) found that the application of poultry waste increased the activity of the urease enzyme in the cowpea's rhizosphere due to the role of organic matter as a source of energy and food for microorganisms as well as for the plant. Thus, it affects the surface area of the roots, leading to a positive increase in their secretions from enzymes. This increase depends on the levels of the organic matter due to its effect on changes in the activity of the microorganisms. Al-Taweel (2015) found in her study of green beans and tomato rhizosphere that increased levels of organic matter (compost) increased enzymatic activity. This may be due to the increased growth and activity of the microorganisms present in the rhizosphere, as the compost is a source of energy and food necessary for the growth of the organisms. As the most important role is for microorganisms, as with their growth and biomass, the amount of enzyme excreted outside the cell will increase, regardless of the presence or absence of the plant.

The results also showed that the activity of urease enzyme increased significantly with increased urea levels (M1) (M2 (29.65 and 34.30) $\mu \mathrm{g} \mathrm{N}-\mathrm{NH}_{4}{ }^{+} \cdot \mathrm{g}^{-1}$ soil.2h ${ }^{-1}$, respectively, for the rhizosphere (29.42 and 30.69) $\mu \mathrm{g} \mathrm{N}-\mathrm{NH}_{4}{ }^{+} . \mathrm{g}^{-1}$ soil. $2 \mathrm{~h}^{-1}$, respectively, for the bulk soil compared to the comparison treatment. Jian et al. (2016) confirmed that nitrogen fertilization boosted microbial biomass and thus helped these microorganisms to produce enzymes outside their cells. This is consistent with what Jarallah (1998) found in his study of the biological transformations of urea fertilizer, where it was found that the highest rate of urease enzyme activity was when treating urea fertilizer compared to sulfur-coated urea. This is also consistent with (Abo-Tabikh, 2019). The reason is that the application of nitrogen fertilizers to the soil provides a nitrogenous source that microorganisms need, including enzymes, which in turn secrete the enzymes in addition to the need for the plant to increase the size of the root system, and thus the amount of root secretions increases.

The results of Table (4) present that the Di combination between the treatment of poultry waste, urea fertilizer (OM1 and OM2), urea fertilizer, and Pseudomonas fluorescens (BM1 and BM2) had a significant effect on urease enzyme activity. The treatment of poultry waste and biofertilizer (OB) (Pseudomonas fluorescens) achieved the highest increase in the efficacy value (54.47) $\mu \mathrm{g} \mathrm{N}-\mathrm{NH}_{4}{ }^{+} \cdot \mathrm{g}^{-1} \mathrm{soil}^{-2} \mathrm{~h}^{-1}$ for the area within the rhizosphere and (49.14) $\mu \mathrm{g} \mathrm{N}-\mathrm{NH}_{4}{ }^{+} . \mathrm{g}^{-1}$ soil. $2 \mathrm{~h}^{-1}$ in bulk soil compared to the control. (Perucci et al., 1982) mentioned that the fact that urea is degraded in the soil by the microbial enzymatic system, this proves that the activity of the urease enzyme increases with the increase in the content of organic matter in the soil because it is an important source of energy processing for the living, which increases its activity in the production of enzymes. (Kandeler and Eder, 1993) explained the increase in urease activity in the surface layer $(0-10) \mathrm{cm}$ from weed lands treated with goat residues as being due to increased biomass and increased enzymatic production. This increase in urease enzyme activity was also attributed to an increase in the activity of the applied Pseudomonas fluorescens.

It is also attributed to the important role of residues in influencing microorganisms by supplying them with energy and some components necessary for building their bodies and carrying out their activities such as the secretion of oxins, enzymes, cytokines and other substances stimulating plant growth that lead to increased root density and secretions (Wallenstein et al., 2011; Khaeim, 2013). 
As shown in Table (4), the treatment of Tri mixture between poultry residues and urea fertilizer at the second level

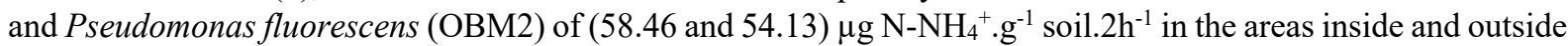
rhizosphere, respectively, achieved the highest significant increase in the activity value of urease enzyme compared to unilateral and bilateral treatments. The table shows an increase in the activity of the urease enzyme in the rhizosphere than that outside the rhizosphere, and the reason is that the rhizosphere is a region rich in root secretions, including the enzyme. It includes a urease enzyme (Pinton et al., 2007). The increased growth is linked to carbonaceous materials secreted by the roots, and some of these microorganisms are responsible for urease production, leading to increased efficacy in this region (Nelson, 2004).

Table 4. The effect of the study treatments on the activity of urease enzyme ( $\mu \mathrm{g} \mathrm{N}-\mathrm{NH}_{4}{ }^{+} \cdot \mathrm{g}^{-1}$ soil. $\left.^{-\mathrm{h}^{-1}}\right) 30$ days after planting

\begin{tabular}{lll}
\hline \multirow{2}{*}{ Treatments } & \multicolumn{2}{l}{ Sampling area } \\
\cline { 2 - 3 } & Rhizosphere soil & Bulk soil \\
\hline Cont & 23.67 & 21.57 \\
O & 44.64 & 39.29 \\
M1 & 29.65 & 29.42 \\
M2 & 34.30 & 30.69 \\
B & 45.22 & 42.54 \\
OM1 & 47.76 & 40.97 \\
OM2 & 50.46 & 41.51 \\
OB & 54.47 & 49.14 \\
BM1 & 50.88 & 47.60 \\
BM2 & 53.19 & 48.12 \\
OBM1 & 55.25 & 50.41 \\
OBM2 & 58.46 & 54.13 \\
L.S.D. & Treatment & Area \\
& 2.61 & 0.85 \\
\hline
\end{tabular}

\subsubsection{The Activity of the Urease Enzyme $\left(\mu \mathrm{g} \mathrm{N}-\mathrm{NH}_{4}{ }^{+} \cdot \mathrm{g}^{-1}\right.$ soil.2h$\left.{ }^{-1}\right) 60$ Days after Planting}

The results presented in Table (5) show the effect of the application of poultry wastes, urea, and bacterial fertilizer (Pseudomonas fluorescens) on the activity of urease enzyme after (60) days of planting. The fertilizer treatment (B) Pseudomonas fluorescens recorded the highest significant increase in the activity value of urease enzyme for and outside the rhizosphere regions (45.34 and 43.16) $\mu \mathrm{g} \mathrm{N}-\mathrm{NH}_{4}{ }^{+} \cdot \mathrm{g}^{-1}$ soil.2h $\mathrm{h}^{-1}$, respectively, compared to the comparison treatment that recorded the least value for urease enzyme activity (23.76 and 21.66) $\mu \mathrm{g} \mathrm{N}-\mathrm{NH}_{4}{ }^{+} . \mathrm{g}^{-1}$ soil. $2 \mathrm{~h}^{-1}$. (Tietgen and Wetxel, 2003) also confirmed that Pseudomonas also can produce urease (Yassin, 2010) emphasized the role of inoculation in Pseudomonas fluorescens in increasing nitrogen availability in the soil, which is one of the important factors in stimulating the activity of the urease enzyme. The treatment of poultry waste $(\mathrm{O})$ achieved a significant increase in enzyme activity in and outside the rhizosphere (44.73 and 40.00), respectively, compared to the comparison treatment. Conrad Burns et al. (1940a) (1972 a, b) indicated that the activity of soil enzymes increases with the increase of organic carbon because the organic matter added to the soil is a source of energy and food for the enzyme-producing organisms as well as the organic matter works to remove the enzyme from the effect of the protease enzyme that analyzes protein.

This is consistent with what (Al Taweel, 2015) found in her study on the green bean rhizosphere. There was a significant increase in enzyme activity following the addition of the organic material (compost). It was attributed to the reason that the activity of the urease enzyme increases with the increase of organic matter, which leads to an increase in the activity of the enzyme secreted by the microorganisms.

The results also showed that the activity of the urease enzyme increased significantly with an increase in the added urea levels (M1) and (M2) (29.74 and 34.39) $\mu \mathrm{g} \mathrm{N}-\mathrm{NH}_{4}{ }^{+} \cdot \mathrm{g}^{-1}$ soil. $2 \mathrm{~h}^{-1}$, respectively, for the rhizosphere (29.51 and 30.78) $\mu \mathrm{g} \mathrm{N}-\mathrm{NH}_{4}{ }^{+} . \mathrm{g}^{-1}$ soil. $2 \mathrm{~h}^{-1}$, respectively, for the region outside the rhizosphere compared to the comparison treatment. The reason is attributed to the fact that increasing the nitrogen ratio in the soil leads to an increase in biological activity, as nitrogen is one of the basic elements in the formation of protein and the amino acids that make up the enzyme and one of the basic elements of most microorganisms that in turn secrete the enzymes into the soil, (Sahrawat, 1983; Aljawasim et al., 2020). 
In a study by Gracia et al. (1994), it was established that the pure isolates of Pseudomonas spp that were laboratory isolated from the soil increased their numbers by adding urea fertilizer and this led to an increase in the activity of the urease enzyme secreted by them due to the increased concentration of the subject. The activity of the enzyme also decreased by decreasing the concentration of the urea subject that the activity of this enzyme has a direct effect on the mineral process that affects the nitrogen availability, which is one of the main factors for increasing the activity of the urease enzyme.

The results of Table (5) showed that the bilateral interactions between the treatment of poultry waste, urea fertilizer (OM1 and OM2), urea fertilizer, and Pseudomonas fluorescens (BM1 and BM2) had a significant effect on urease enzyme activity. The treatment of poultry waste and biofertilizer $(\mathrm{OB})$ achieved the highest significant increase in the activity value (54.56) $\mu \mathrm{g} \mathrm{N}-\mathrm{NH}_{4}{ }^{+} \cdot \mathrm{g}^{-1}$ soil. $2 \mathrm{~h}^{-1}$ for the area within the rhizosphere and (49.23) $\mu \mathrm{g} \mathrm{N}-\mathrm{NH}_{4}{ }^{+} \cdot \mathrm{g}^{-1}$ soil. $2 \mathrm{~h}^{-1}$ for an area outside the rhizosphere compared to unary treatments. The reason and the positive effect of the organic matter are attributed to the increase in the growth and secretions of roots and this is consistent with what Coelho and others (2016) found that the application of the organic matter in the soil increases the growth and development of the roots and the increase of microorganisms.

As shown in Table (5), the treatment of triple interference between poultry residues and urea fertilizer at the second level and Pseudomonas fluorescens (OBM2) of (58.55 and 54.22) $\mu \mathrm{g} \mathrm{N}-\mathrm{NH}_{4}{ }^{+} \cdot \mathrm{g}^{-1} \mathrm{soil}^{-2 \mathrm{~h}^{-1}}$ in the areas inside and outside rhizosphere, respectively, achieved the highest significant increase in the value of enzymatic activity compared to mono and bilateral treatments.

From Table (5), it is clear that the activity of the urease enzyme in 60 days was higher than 30 days. The reason is due to the increase in plant growth and the increase in the density of the roots and the hormones they produce that are important for the multiplication of microorganisms and increase their numbers, thus increasing the biomass and the enzymes that attract the nitrogen-fixing organisms.

Also, some microorganisms are exposed to death and decomposition, which leads to the proliferation of nitrogen compounds that were installed in their bodies, which is one of the important elements to increase the activity of the urease enzyme and increase its quantity in the rhizosphere and bulk soils (Kuo et al., 1997).

Table 5. The effect of the study treatments on the activity of the urease enzyme ( $\left.\mu \mathrm{g} \mathrm{N}-\mathrm{NH}_{4}{ }^{+} \cdot \mathrm{g}^{-1} \mathrm{soil} .2 \mathrm{~h}^{-1}\right) 60$ days after planting

\begin{tabular}{lll}
\hline \multirow{2}{*}{ Treatments } & Sampling area & \\
\cline { 2 - 3 } & Rhizosphere soil & Bulk soil \\
\hline Cont & 23.76 & 21.66 \\
O & 44.73 & 40.00 \\
M1 & 29.74 & 29.51 \\
M2 & 34.39 & 30.78 \\
B & 45.34 & 43.16 \\
OM1 & 47.85 & 41.06 \\
OM2 & 50.55 & 47.15 \\
OB & 54.56 & 49.23 \\
BM1 & 50.97 & 41.6 \\
BM2 & 53.28 & 48.21 \\
OBM1 & 55.34 & 50.50 \\
OBM2 & 58.55 & 54.22 \\
L.S.D. & Treatment & Area \\
& 2.18 & 0.85 \\
\hline
\end{tabular}

3.2 The effect of the fertilizer Pseudomonas Fluorescens, Poultry Wastes and Urea on the Activity of the Lclutamines enzyme ( $\mu \mathrm{g} \mathrm{N}-\mathrm{NH}_{4}{ }^{+} \cdot \mathrm{g}^{-1}$ soil.2h$\left.h^{-1}\right)$ in the Rhizosphere and Bulk Soils of Mung Bean Crop after 30 and 60 Days of Cultivation

3.2.1 The Activity of_L-clotamene ( $\mu \mathrm{g} \mathrm{N}-\mathrm{NH}_{4}{ }^{+} \cdot \mathrm{g}^{-1}$ soil. $\left.2 \mathrm{~h}^{-1}\right) 30$ Days After Planting

The results presented in Table (6) present the effect of the application of poultry wastes, urea, and bacterial fertilizer Pseudomonas fluorescens on the activity of L-clotamines after (30) days of cultivation. The treatment of poultry residues $(\mathrm{O})$ achieved the highest significant increase in the value of the activity of the enzyme of LClutamnes in the rhizosphere and bulk soils (43.47 and 57.39) $\mu \mathrm{g} \mathrm{N}-\mathrm{NH}_{4}{ }^{+} \cdot \mathrm{g}^{-1}$ soil. $2 \mathrm{~h}^{-1}$, respectively, compared to 
the comparison treatment, which made the least value for L-glutaminase activity (18.20 and 13.47) $\mu \mathrm{g} \mathrm{N}-\mathrm{NH}_{4}{ }^{+} \cdot \mathrm{g}^{-}$ ${ }^{1}$ soil. $2 \mathrm{~h}^{-1}$, respectively, for the region of the rhizosphere and bulk soil. The reason is attributed to the importance of organic matter as a source of energy, carbon, and other nutrients that microorganisms need to grow and increase their activity, which helps them maintain their metabolic activities, including their enzyme release. It also works to protect the enzyme from the decomposition processes that it is exposed to by the protease enzyme, which works to decompose the enzyme protein, as the enzymes are adsorbed on the surface of the organic matter, thus increasing the amount of the enzyme by increasing the addition of the organic matter (Jian et al., 2016).

The treatment of bio-fertilizer (B) Pseudomonas fluorescens achieved an increase in the activity value of the enzyme L-Clotamnes in the rhizosphere and bulk soils (38.58 and 35.50) $\mu \mathrm{g} \mathrm{N}-\mathrm{NH}_{4}{ }^{+} . \mathrm{g}^{-1}$ soil. $^{-1} \mathrm{~h}^{-1}$, respectively, compared to the comparison treatment. The reason for the increase is because Pseudomonas fluorescens increase the density of the biomass, as these bacteria can fix nitrogen and represent it and decompose complex organic compounds such as lignin, cellulose, butene, proteins, and urea. This material is an energy source for the organisms that secrete the enzyme by secreting many aqueous enzymes (Aeschbacher, 2010).

The results also showed that the activity of the enzyme L-clotamene increased significantly with an increase in the

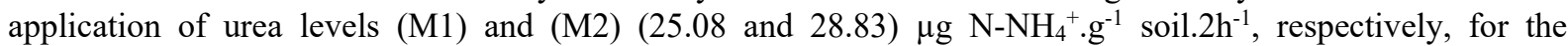
rhizosphere (21.75 and 22.92) $\mu \mathrm{g} \mathrm{N}-\mathrm{NH}_{4}{ }^{+} \cdot \mathrm{g}^{-1}$ soil. $2 \mathrm{~h}^{-1}$, respectively, for the bulk soil compared to the comparison coefficient. The reason for the increase is attributed to the fact that the chemical fertilization process affected the physiological characteristics of the plant by increasing the photosynthesis components that lead to an increase in the root group and an increase in its attracting secretions to the secreted organisms of the types of enzymes as well as the secretion of the roots themselves for enzymes in the region of the rhizosphere (Makinde et al., 2010).

The results of Table (6) showed that the Di combination between the treatment of poultry waste, urea fertilizer (OM1 and OM2), urea fertilizer, and Pseudomonas fluorescens (BM1 and BM2) had a significant effect on the activity of L-clotamines. The treatment of poultry waste and biofertilizer (OB) (Pseudomonas fluorescens) achieved the highest significant increase in the activity value (46.84) $\mu \mathrm{g} \mathrm{N}-\mathrm{NH}_{4}{ }^{+} \cdot \mathrm{g}^{-1}$ soil. $2 \mathrm{~h}^{-1}$ for the area within the rhizosphere and (37.81) $\mu \mathrm{g} \mathrm{N}-\mathrm{NH}_{4}{ }^{+} \cdot \mathrm{g}^{-1}$ soil. $2 \mathrm{~h}^{-1}$ for the bulk soil compared to unary treatments. The reason is attributed to the positive effect of the organic matter on increasing the growth and secretions of roots and this is consistent with what Coelho and others (2016) found that the application of organic matter in the soil increases the growth and development of roots and the increase of microorganisms.

As shown in Table (6), the treatment of Tri mixture between poultry residues and urea fertilizer at the second level and Pseudomonas fluorescens (OBM2) of (48.58 and 46.30) $\mu \mathrm{g} \mathrm{N}-\mathrm{NH}_{4}{ }^{+} \cdot \mathrm{g}^{-1}$ soil. $2 \mathrm{~h}^{-1}$ in the areas inside and outside rhizosphere, respectively, achieved the highest significant increase in the value of enzymatic activity compared to mono and bilateral treatments.

Table 6. The effect of the study treatments on the activity of L-clotamines enzyme $\left(\mu \mathrm{g} \mathrm{N}-\mathrm{NH}_{4}^{+} \cdot \mathrm{g}^{-1}\right.$ soil. $\left.2 \mathrm{~h}^{-1}\right) 30$ days after planting

\begin{tabular}{lll}
\hline \multirow{2}{*}{ Treatments } & Sampling area & \\
\cline { 2 - 3 } & Rhizosphere soil & Bulk soil \\
\hline Cont & 18.20 & 13.47 \\
O & 43.47 & 39.57 \\
M1 & 25.08 & 21.75 \\
M2 & 28.83 & 22.92 \\
B & 38.58 & 35.50 \\
OM1 & 41.64 & 39.43 \\
OM2 & 42.18 & 40.71 \\
OB & 46.84 & 37.81 \\
BM1 & 37.65 & 35.74 \\
BM2 & 40.26 & 37.14 \\
OBM1 & 47.06 & 42.75 \\
OBM2 & 48.58 & 46.30 \\
L.S.D. & Treatment & Area \\
& 0.13 & 0.95 \\
\hline
\end{tabular}




\subsubsection{The Activity of L-Clotamene ( $\mu \mathrm{g} \mathrm{N}-\mathrm{NH}_{4}^{+} \cdot \mathrm{g}^{-1}$ soil. $\left.2 h^{-1}\right) 60$ Days After Planting}

The results presented in Table (7) present the effect of the application of poultry wastes, urea and bacterial fertilizer, Pseudomonas fluorescens, on the activity of L-glutaminase after (60) days of cultivation. The treatment of poultry residues $(\mathrm{O})$ achieved the highest significant increase in the value of the activity of the L-clutamines in the rhizosphere and bulk soils (44.33 and 40.43) $\mu \mathrm{g} \mathrm{N}-\mathrm{NH}_{4}{ }^{+} \cdot \mathrm{g}^{-1}$ soil. $2 \mathrm{~h}^{-1}$, respectively, compared to the comparison treatment, which was recorded the least value of the L-glutaminase activity (19.05 and 14.33) $\mu \mathrm{g} \mathrm{N}-\mathrm{NH}_{4}{ }^{+} \cdot \mathrm{g}^{-1}$ soil. $2 \mathrm{~h}^{-1}$, respectively, for the region of the rhizosphere and beyond.

The reason for the increase in the activity of L-clutamines is that organic matter applications have an important effect in increasing the numbers of microorganisms by supplying the biota with nutrients and providing a suitable medium for their growth and reproduction and increasing their enzymatic secretions (Okabe et al., 2012). Frnkenberger and Tabatabai (1991) found that the L-clotamines increased their activity with the application of organic fertilizers and attributed the reason to the role of the organic material in improving the physical, chemical, and biological soil properties of the soil as well as improving the nutritional status of the plant. Thus increasing its secretions important to microorganisms as well as containing organic fertilizer of the three important elements, which are nitrogen, phosphorus, and potassium in the nutrition of microorganisms.

The treatment of bio-fertilizer (B) Pseudomonas fluorescens achieved a significant increase in the activity value

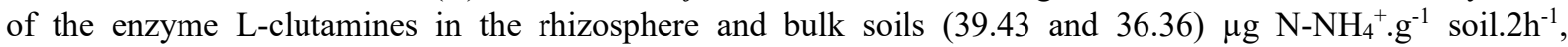
respectively, compared to the comparison treatment. The reason for the increase is because these bacteria, as a biological inoculation, work to form a vital community that supplies the soil after the death of these microorganisms and decomposes them with carbon and various elements as well as organic acids, enzymes and proteins during their metabolic activities (Ahmed and El-Abagy, 2007).

The results also showed that the activity of the enzyme L-clotamene increased significantly with increasing urea levels added (M1) and (M2) (29.65 and 34.30) $\mu \mathrm{g} \mathrm{N}-\mathrm{NH}_{4}{ }^{+} \cdot \mathrm{g}^{-1}$ soil. $2 \mathrm{~h}^{-1}$, respectively for the rhizosphere and (25.94 and 29.69) $\mu \mathrm{g} \mathrm{N}-\mathrm{NH}_{4}{ }^{+} \cdot \mathrm{g}^{-1}$ soil. $2 \mathrm{~h}^{-1}$, respectively, for the bulk soil compared to the treatment of the comparison. The reason for the increase is because the chemical fertilization process had a significant effect on the physiological characteristics of the plant by increasing the components of photosynthesis, which leads to an increase in the root group and an increase in its attracting secretions to the organisms producing types of enzymes as well as the secretions of the roots themselves in the region of the rhizosphere and bulk soils (Makinde et al., 2010).

The results of Table (7) showed that the bilateral interactions between the treatment of poultry waste, urea fertilizer (OM1 and OM2), urea fertilizer, and fluorescens Pseudomonas (BM1 and BM2) had a significant effect on the activity of L-clotamines. The treatment of poultry waste and bio-fertilizer (OB) Pseudomonas fluorescens achieved the highest increase in the activity value (47.69) $\mu \mathrm{g} \mathrm{N}-\mathrm{NH}_{4}{ }^{+} \cdot \mathrm{g}^{-1}$ soil. $2 \mathrm{~h}^{-1}$ for the region within the rhizosphere and (38.67) $\mu \mathrm{g} \mathrm{N}-\mathrm{NH}_{4}{ }^{+} \cdot \mathrm{g}^{-1}$ soil. $2 \mathrm{~h}^{-1}$ for the bulk soil compared to unary treatment. The reason is attributed to the role of bio-fertilizers in increasing the readiness of nutrients, as well as their role in the secretion of some enzymes, growth regulators and plant hormones, and their importance to plants, as well as their importance in the decomposition of organic wastes that have an important role in influencing soil biology by supplying them with energy and some components needed to build its bodies and its activities of reproduction and external metabolic activity. The activity of the enzyme is directly related to the activity of microorganisms (Al-Wahaibi, 2008).

As shown in Table (7), the treatment of Tri combination between poultry residues and urea fertilizer at the second level and Pseudomonas fluorescens (OBM2) and (49.44 and 47.15) $\mu \mathrm{g} \mathrm{N}-\mathrm{NH}_{4}{ }^{+} \cdot \mathrm{g}^{-1} \mathrm{soil}^{-2 \mathrm{~h}^{-1}}$ in the regions inside and outside rhizosphere, respectively, achieved the highest significant increase in the activity of L-clotamene enzyme compared to mono and binary treatments. Table (7) shows that the activity of L-clotamines in the 60 days was higher than the 30 days. The reason for this is due to the growth and increase of the area of the root group and the increase in its secretions in the soil, as well as the time required for the decomposition of most of the organic matter and the elements that it provides, are important for the growth of the organisms and provide a suitable medium for them, which makes the rhizosphere and outside it a region rich with microorganisms and their secretions of enzymes during those periods (Juan et al., 2010). 
Table 7. The effect of the study treatments on the activity of L-clotamines enzyme $\left(\mu \mathrm{g} \mathrm{N}-\mathrm{NH}_{4}{ }^{+} \cdot \mathrm{g}^{-1} \mathrm{soil} .2 \mathrm{~h}^{-1}\right) 60$ days after planting

\begin{tabular}{lll}
\hline \multirow{2}{*}{ Treatments } & \multicolumn{2}{l}{ Sampling area } \\
\cline { 2 - 3 } & Rhizosphere soil & Bulk soil \\
\hline Cont & 19.05 & 14.33 \\
O & 44.33 & 40.43 \\
M1 & 25.94 & 22.60 \\
M2 & 29.69 & 23.78 \\
B & 39.43 & 36.36 \\
OM1 & 42.5 & 40.28 \\
OM2 & 43.03 & 41.56 \\
OB & 47.69 & 38.67 \\
BM1 & 38.51 & 36.60 \\
BM2 & 41.12 & 38.00 \\
OBM1 & 47.89 & 43.61 \\
OBM2 & 49.44 & 47.15 \\
L.S.D. & Treatment & Area \\
& 2.35 & 0.92 \\
\hline
\end{tabular}

3.2 The Effect of the Biofertilizer Pseudomonas Fluorescens, Poultry Wastes, and Urea on the Activity of LAspartase $\left(\mu \mathrm{g} \mathrm{N}-\mathrm{NH}_{4}{ }^{+} \cdot \mathrm{g}^{-1}\right.$ soil. $\left.2 h^{-1}\right)$ in the Rhizosphere and Bulk Soils of Mung Bean Crop after 30 and 60 days of Cultivation.

\subsubsection{The Activity of L-Aspartase $\left(\mu \mathrm{g} \mathrm{N}-\mathrm{NH}_{4}{ }^{+} \cdot \mathrm{g}^{-1}\right.$ soil.2h $\left.{ }^{-1}\right) 30$ Days after Planting}

The results presented in Table (8) show the effect of adding poultry wastes, urea, and bacterial fertilizer on the activity of L-aspartase after (30) days of cultivation. The B fertilizer treatment (Pseudomonas fluorescens) resulted in the highest significant increase in the activity value of the enzyme L-aspartase for the rhizosphere and bulk soils (25.89 and 24.72) $\mu \mathrm{g} \mathrm{N}-\mathrm{NH}_{4}{ }^{+} \cdot \mathrm{g}^{-1}$ soil. $2 \mathrm{~h}^{-1}$, respectively, compared to the comparison treatment, which recorded the least value of enzyme activity (12.82 and 12.16) $\mu \mathrm{g} \mathrm{N}-\mathrm{NH}_{4}^{+} \cdot \mathrm{g}^{-1}$ soil. $2 \mathrm{~h}^{-1}$. The reason for the increased activity when bio-composting is that the Pseudomonas fluorescens are working to produce different enzymes or that their addition has encouraged increased intensity and activity of other enzyme-secreted organisms (Katila et al., 2013; Jeber et al., 2019).

The treatment of poultry waste $(\mathrm{O})$ achieved a significant increase in the enzyme activity in and outside the rhizosphere as it reached (25.51 and 24.04) $\mu \mathrm{g} \mathrm{N}-\mathrm{NH}_{4}{ }^{+} \cdot \mathrm{g}^{-1}$ soil. $2 \mathrm{~h}^{-1}$, respectively, compared to the comparison treatment. The reason for this is due to the ability of organic fertilizers to make nutrients readily available to the plant and increase vital activity in the root zone, thereby increasing secretions with low molecular weights dissolved in water such as sugars, organic acids, amino acids and phenols, hormones, vitamins and secretions with high molecular weights such as polysaccharides and enzymes (Yoshimune, 2010). The results also showed that the activity of L-aspartase increased significantly with increased urea levels (M1) and (M2) (16.93 and 19.16) $\mu \mathrm{g}$ $\mathrm{N}-\mathrm{NH}_{4}{ }^{+} \cdot \mathrm{g}^{-1}$ soil. $2 \mathrm{~h}^{-1}$, respectively for the rhizosphere (17.04 and 17.40) $\mu \mathrm{g} \mathrm{N}-\mathrm{NH}_{4}{ }^{+} \cdot \mathrm{g}^{-1}$ soil. $^{2} \mathrm{~h}^{-1}$, respectively, for the bulk soil compared to the comparison treatment. The reason is attributed to the fact that increasing the nitrogen ratio in the soil leads to an increase in biological activity, as nitrogen is one of the basic elements in the formation of protein and the amino acids that make up the enzyme, and that it is one of the basic elements of most microorganisms that in turn secrete enzymes into the soil (Brown, 2008).

The results of Table (8) showed that the Di combination between the treatment of poultry waste, urea fertilizer (OM1 and OM2), urea fertilizer, and Pseudomonas fluorescens (BM1 and BM2) had a significant effect on the activity of L-aspartase. The treatment of poultry waste and biofertilizer (OB) (Pseudomonas fluorescens) made the highest significant increase in the activity value (28.28) $\mu \mathrm{g} \mathrm{N}-\mathrm{NH}_{4}{ }^{+} \cdot \mathrm{g}^{-1}$ soil.2 $\mathrm{h}^{-1}$ for the area within the rhizosphere and (23.94) $\mu \mathrm{g} \mathrm{N}-\mathrm{NH}_{4}{ }^{+} \cdot \mathrm{g}^{-1}$ soil. $2 \mathrm{~h}^{-1}$ for the bulk soil. The reason for the increase in the activity of Lclutamines is that organic additives have an important effect in increasing the numbers of microorganisms by supplying the biota with nutrients and providing a suitable medium for their growth and reproduction and increasing their enzymatic secretions (Okabe et al., 2012).

As shown in Table (8), the treatment of Tri mixture between poultry residues and urea fertilizer at the second level

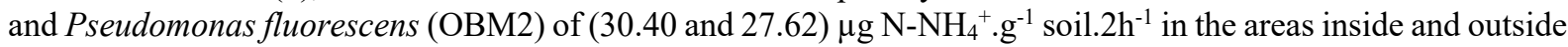
Rhizosphere, respectively, has achieved the highest significant increase in the activity of L-aspartase in comparison 
with mono and binary treatments. In general, the table shows an increase in the value of enzyme activity in the rhizosphere compared to the bulk soil. The reason is attributed to the secretions of the various roots in the root ocean region through which the biomass is maintained and its activity which is much higher than the soil far from the roots of the plant in addition to the root secretions that are hydrolysis enzymes (Okabe et al., 2012).

Table 8. The effect of the study treatments on the activity of L-aspartase enzyme $\left(\mu \mathrm{g} \mathrm{N}-\mathrm{NH}_{4}{ }^{+} \cdot \mathrm{g}^{-1}\right.$ soil. $\left.2 \mathrm{~h}^{-1}\right) 30$ days after planting

\begin{tabular}{lll}
\hline \multirow{2}{*}{ Treatments } & \multicolumn{2}{l}{ Sampling area } \\
\cline { 2 - 3 } & Rhizosphere soil & Bulk soil \\
\hline Cont & 12.82 & 12.16 \\
O & 25.51 & 24.04 \\
M1 & 16.93 & 16.04 \\
M2 & 19.16 & 17.40 \\
B & 25.89 & 24.72 \\
OM1 & 25.67 & 23.62 \\
OM2 & 27.48 & 23.83 \\
OB & 28.28 & 23.94 \\
BM1 & 24.16 & 22.92 \\
BM2 & 25.04 & 23.03 \\
OBM1 & 29.42 & 26.84 \\
OBM2 & 30.40 & 27.62 \\
L.S.D. & Treatment & Area \\
& 0.13 & 0.05 \\
\hline
\end{tabular}

\subsubsection{The Activity of L-Aspartase $\left(\mu \mathrm{g} \mathrm{N}-\mathrm{NH}_{4}{ }^{+} \cdot \mathrm{g}^{-1}\right.$ soil. $\left.2 \mathrm{~h}^{-1}\right) 60$ days After Planting}

The results presented in Table (9) present the effect of poultry wastes, urea, and bacterial fertilizer (Pseudomonas fluorescens) application on the activity of L-aspartase after (60) days of the planting date. The fertilizer treatment (B) Pseudomonas fluorescens resulted in the highest significant increase in the activity value of L-aspartase in and outside the rhizosphere (26.23 and 25.06) $\mu \mathrm{g} \mathrm{N}-\mathrm{NH}_{4}^{+} \cdot \mathrm{g}^{-1}$ soil. $2 \mathrm{~h}^{-1}$, respectively, compared to the comparison treatment, which recorded the lowest value for enzyme activity (13.17 and 12.50) $\mu \mathrm{g} \mathrm{N}-\mathrm{NH}_{4}{ }^{+} \cdot \mathrm{g}^{-1} \mathrm{soil}^{-2} \mathrm{~h}^{-1}$. The reason is attributed to the role of bacteria in the production of multiple enzymes, including L-aspartase, the importance of roots and their attractive secretions to microorganisms in soil producing hydrolysis enzymes (Sinsabaugh et al., 2005).

The treatment of poultry waste $(\mathrm{O})$ achieved a significant increase in the value of enzyme activity in and outside the rhizosphere (25.85 and 24.38) $\mu \mathrm{g} \mathrm{N}-\mathrm{NH}_{4}{ }^{+} . \mathrm{g}^{-1}$ soil. $2 \mathrm{~h}^{-1}$, respectively, compared to the comparison treatment. The reason for the high activity is due to the role of the organic matter, which increases the biomass as a source of energy and carbon for microorganisms, and this, in turn, increases the secretion of enzymes by the microorganisms, in addition to providing the plant with the nutrients necessary for growth, thus increasing the root secretions that include the enzymes (sparling, 1992). Dodar and Tabatabai's (2003) study showed a significant association between organic matter content and soil enzyme activity. The results also showed that the activity of L-aspartase increased significantly with increased urea levels (M1) (M2 (17.74 and 19.50) $\mu \mathrm{g} \mathrm{N}-\mathrm{NH}_{4}{ }^{+} \cdot \mathrm{g}^{-1} \mathrm{soil}^{-2 \mathrm{~h}^{-1}}$, respectively, for the rhizosphere (16.38 and 17.74) $\mu \mathrm{g} \mathrm{N}-\mathrm{NH}_{4}^{+} \cdot \mathrm{g}^{-1}$ soil. $2 \mathrm{~h}^{-1}$, respectively, for the region of bulk soil compared to the comparison treatment. The reason is attributed to the effect of the application of urea nitrogen fertilizer on the activity of enzymes and organic carbon in the soil. It was found that mineral fertilization increases the biomass and organic matter, and urea supplementation stimulated the production of exogenous enzymes such as Lclutamines and L-aspartase (Blank, 2004). Bergstrom et al. (1998) also found that the activity of L-aspartase increased when using urea fertilizers compared to the control treatment, and the reason was attributed to the role of nitrogen fertilizer in stimulating organisms and roots to produce enzymes, including L-aspartase in the rhizosphere and bulk soil.

The results of Table (9) showed that the Di combination between the treatment of poultry waste, urea fertilizer (OM1 and OM2), urea fertilizer, and Pseudomonas fluorescens (BM1 and BM2) had a significant effect on the activity of L-aspartase. The treatment of poultry waste and biofertilizer OB (Pseudomonas fluorescens) achieved the highest increase in the activity value (28.62) $\mu \mathrm{g} \mathrm{N}-\mathrm{NH}_{4}{ }^{+} \cdot \mathrm{g}^{-1} \mathrm{soil} \cdot 2 \mathrm{~h}^{-1}$ for the area inside the rhizosphere and (24.18) $\mu \mathrm{g} \mathrm{N}-\mathrm{NH}_{4}{ }^{+} \cdot \mathrm{g}^{-1}$ soil. $2 \mathrm{~h}^{-1}$ for the bulk soil compared to other mono and binary treatment. 
The reason is attributed to the fact that the organic matter added to the soil increases the organic carbon in the soil, which is the main energy source for the microorganisms present in the soil as well as the organic matter (poultry waste) contains various nutrients such as nitrogen, phosphorous, sulfur and other elements that increase society of the biosynthesis of the rhizosphere increases the size of the root branching and, consequently, increases its secretions that attract microorganisms that increase the number of enzymes secreted in the root zone of the plant (Aeschbacher, 2010).

The treatment of Tri combination between poultry residues and urea fertilizer at the second level and Pseudomonas fluorescens (OBM2) of (30.74 and 27.96) $\mu \mathrm{g} \mathrm{N}-\mathrm{NH}_{4}{ }^{+} \cdot \mathrm{g}^{-1}$ soil. $2 \mathrm{~h}^{-1}$ in the areas inside and outside Rhizosphere, respectively, achieved the highest significant increase in the value of enzyme activity compared to mono and bilateral treatments. The activity of L-aspartase in the 60 days recorded the highest increase in the activity value compared to the 30 days. These results show that the activity of the enzyme is affected by factors including biomass and its activity. The larger the biomass in the soil, the more activity the enzyme. This was observed after 60 days of germination, which reflects the increase in the number of microorganisms compared to the period of 30 days. (Dodar and Tabatabai, 2003) showed a significant association between biomass and enzyme activity measured in soil.

Table 9. The effect of the study treatments on the activity of $\mathrm{L}$-aspartase enzyme ( $\mu \mathrm{g} \mathrm{N}-\mathrm{NH}_{4}{ }^{+} \cdot \mathrm{g}^{-1}$ soil. $\left.2 \mathrm{~h}^{-1}\right) 60$ days after planting

\begin{tabular}{lll}
\hline \multirow{2}{*}{ Treatments } & \multicolumn{2}{l}{ Sampling area } \\
\cline { 2 - 3 } & Rhizosphere soil & Bulk soil \\
\hline Cont & 13.17 & 12.5 \\
O & 25.85 & 24.38 \\
M1 & 17.27 & 16.38 \\
M2 & 19.5 & 17.74 \\
B & 26.23 & 25.06 \\
OM1 & 26.01 & 23.96 \\
OM2 & 27.82 & 24.17 \\
OB & 28.62 & 24.18 \\
BM1 & 24.50 & 23.26 \\
BM2 & 25.38 & 23.37 \\
OBM1 & 29.70 & 27.18 \\
OBM2 & 30.74 & 27.96 \\
L.S.D. & Treatment & Area \\
& 0.19 & 0.07 \\
\hline
\end{tabular}

\section{Conclusions}

1. The addition of poultry residues $(\mathrm{O})$ achieved the highest significant increase in the value of the activity of the enzyme of L-Clutamnes Compared to other individual additives.

2. The addition of the bio-fertilizer Pseudomonas fluorescens (B) increased the effectiveness of urease and Laspartase enzymes in the soil compared to other individual additives.

3. The addition of the bio-fertilizer Pseudomonas fluorescens with poultry residues (OB) resulted in an increase in the efficacy of the urease and L-clotamines and L-aspartase enzymes in comparison with other single and bilateral additives.

4. The addition of the poultry residues, bio-fertilizer, and urea at level II (40 kg.N.h $\left.{ }^{-1}\right)(\mathrm{OBM} 2)$ achieved the highest significant increase in values of all studied enzymes compared to other additives.

\section{References}

Abo-Tabikh, M. M. (2019). Effect of Humic acid and nitrogen fertilizers on the activity of urease enzyme, nitrification and the growth, and yield of Zea mays L., Master Thesis, College of Agriculture, Al-Qadisiyah University.

Abu, P., Falah, \& Muhammad, S. Al-Shater (2011). Soil fertility and fertilization theoretical part. Publications of Damascus University, Faculty of Agriculture.

Aeschbacher, M. S., \& Schwarzenbach, R. P. (2010). Novel Electrochemical Approach To Assess The Redox 
Properties of Humic Acids. Environmental Science \& Technology, 47, 87-93. https://doi.org/10.1021/es902627p

Ahmed, M. A., \& El-Abagy, H. M. H. (2007). Effect of Bio-And Mineral Phosphorus Fertilizeron The Growth, Productivity And Nutritionalvalue Of Some Faba Bean (Vicia Faba, L) Cultivarsin Newly Cultivated Land. J. of Appl. Sci. Res., 3(6), 408-420.

Aljawasim, D. B., Khaeim, M. H., \& Manshood, A. M. (2020). Assessment of arbuscular mycorrhizal fungi (Glomus spp.) as potential biocontrol agents against damping-off disease Rhizoctonia solani on cucumber. Journal of Crop Protection, 9(1), 141-147.

Al-Taweel, L. S. J. (2015). The effect of compost soil salinity on the microbial biomass and the effectiveness of some enzymes in the root zone of beans and tomatoes. Ph.D. thesis. Department of Soil and Water Resources _ College of Agriculture _ Baghdad University.

Al-Taweel, L. S., \& Abo-Tabikh, M. M. (2019). Urea and Ammonium Sulfate Fertilizers and Humic Acid Effect on Urease Enzyme Activity in and out the Rhizosphere of Zea Mays L. Crop. Plant Archives, 19(1), 19051914.

Al-Wahaibi, M. bin H. (2008). Stimulated Ocean Root Bacteria for Plant Growth. Saudi Journal of Macroecological Sciences, 15(3).

Aziz, E. Eman, \& El-Ashry, S. M. (2009). The efficiency of slow-release urea fertilizer on herb yield and essential oil Production of lemon balm (Melissa officinalis L.) plant. American-Eurasian J. Agric. And Environ Sci., 5(2), 141-147.

Barker, A. V., \& Bryso, M. (2007). Nitrogen.In A.V. Barker, And D.J. Pilbeam, (Ed)" Handbook Of Plant Nutrition". CRC Taylor \& Francis Group.

Bergstrom, D. W., \& Monreal, C. M. (1998). Increased soil enzyme activities under two-row crops. Soil. Sci. Soc. Am. J., 62, 1295-1301. https://doi.org/10.2136/sssaj1998.03615995006200050021x

Black. C. A. (1965). Methods Of Soil Analysis Part (1). Physical Properties Am. Soc. Agron. INC. Publisher, Madison, Wisconsin, U.S.A. https://doi.org/10.2134/agronmonogr9.1

Brown. (2008). Functional And Structural Characterization Of Four Glutaminases From Escherichia Coli And Bacillus Subtilis. Biochemistry, 47(21), 5724-5735. https://doi.org/10.1021/bi800097h

Burns, R, G., El-Sayed, M. H., \& McLaren, A. D. (1972a). Extraction of a urease-active organo-complex from the soil. Soil Biol. Biochem, 4,107-108. https://doi.org/10.1016/0038-0717(72)90048-X

Castellano, S. D., \& Dick, R. P. (1991). Cropping and sulfur fertilization influence on sulfur transformation in soil. Soil Sci.Soc. Am. J., 54, 114-121. https://doi.org/10.2136/sssaj1991.03615995005500010020x

Coelho, E. F., Melo, D. M. D., Pereira, B. L., Santos, D. B. D., \&Rosa, R. C. C. (2016). Roots Of 'BRS Princesa' Banana Fertigated With Humic Substances And Saponin-Based Plant Extracts. Acta Scientiarum. Agronomy Maringa, 38(4), 121-528, Oct.-Dec. https://doi.org/10.4025/actasciagron.v38i4.30790

Colombo, C., Palumbo, G., Sannion, F., \& Gianfreda, L. (2002). Chemical And Biochemical Indicators Of Managed Agriculture Soils In:17th World Congress of Soil Science, Bangkok. Thailand. 17402, 1-9.

Conrad, J. P. (1940a). Catalytic activity causing the hydrolysis of urea in soils as influenced by several agronomic factors. Soil. Sci. Soc. Am. Proc., 5, 238-241. https://doi.org/10.2136/sssaj1941.036159950005000C0040x

Dodar, D. E., \& Tabatabai, M. A. (2003). Effect of cropping systems on phosphates in soils. J. pland Nutr. Soil Sci., 166, 7-13. https://doi.org/10.1002/jpln.200390016

Frankenberger W. T. Jr., \& Tabatabai, M. A. (1991) . Factors affecting L-glutaminase activity in soils. Biology and Fertility of Soils, 11, 1-5. https://doi.org/10.1007/BF00335825

Gracia, C; T. Hernandez; F. Costa and B. Ceccanti. (1994). Biochemical parameters in soil regenerated by the addition of organic wastes. Waste Manage. Res., 12, 457-466. https://doi.org/10.1006/wmre.1994.1035

Hinsinger,P.; C. Plassard And B. Jaillarad .(2006). Rhizosphere: A New Frontier For Soil Biogeochemistry. Journal of Geochemical Exploration, 88, 210-213. https://doi.org/10.1016/j.gexplo.2005.08.041

Jarallah, Abbas Khudair Abbas. (1998). Biological transformation of urea fertilizer and its kinetic properties in salinity-affected soils. Master Thesis - College of Agriculture - University of Baghdad.

Jeber, B. A., \& Hussein, M. K. (2019). "EFFECT OF FOLIAR APPLICATION OF AMINO ACIDS, ORGANIC 
ACIDS, AND NAPHTHALENE ACETIC ACID ON GROWTH AND YIELD TRAITS OF WHEAT." Plant Archives, 19(2), 824-826.

Jian, S., Li, J., Chen, J., Wang, G., Mayes, M.A., Dzantor, K. E., Hui, D., \& Luo, Y., (2016). Soil extracellular enzyme activities, soil carbon and nitrogen storage under nitrogen fertilization: A meta-analysis. Soil Biol. Biochem, 101, 32-43. https://doi.org/10.1016/j.soilbio.2016.07.003

Juan, Y. H., Chen, L. J., Wu, Z. J., Wang, R., Sun, W. T., \& Zhang, Y. L. (2010). Kinetic And Thermodynamic Behaviours of Soil Urease as Affected by Urease Inhibitors. R.C Suelo Nutr. Veg., 10(1), 1-11. https://doi.org/10.4067/S0718-27912010000100001

Kandeler, E., \& Eder, G. (1993). Effect of cattle slurry in grassland on microbial biomass and on activities of various enzymes. Boil. Fertil. Soils, 16, 249-254. https://doi.org/10.1007/BF00369300

Katila, V., Lindsey, A. C., Mark, W. S., \& Eduardo, A. R. (2013). Colonization Strategies of Pseudomonas Fluorescens Pf0-1: Activation Of Soil-Specific Genes Important for Diverse and Specific EnvironmentsBMC Microbiology, 13, 92. https://doi.org/10.1186/1471-2180-13-92

Khaeim, H. M. (2013). Mass selection with an optical sorter for head scab resistance in soft red winter wheat.

Khaeim, H. M., Clark, A., Pearson, T., \& Van Sanford, D. (2019). Comparing Genetic Variation within Red Winter Wheat Populations with and without Image-Based Optical Sorter Selection. Al-Qadisiyah Journal For Agriculture Sciences (QJAS)(P-ISSN: 2077-5822, E-ISSN: 2617-1479), 9(2), 266-277. https://doi.org/10.33794/qjas.Vol9.Iss2.82

Khaeim, H. M., Clark, A., Pearson, T., \& Van Sanford, D. (2019). Determining The Effect of Mass Selection for FHB Resistance in Soft Red Winter Wheat Using an Image-Based Optical Sorter. Al-Qadisiyah Journal for Agriculture Sciences (QJAS)(P-ISSN: 2077-5822, E-ISSN: 2617-1479), 9(2), 278-296. https://doi.org/10.33794/qjas.Vol9.Iss2.83

Khaeim, H. M., Clark, A., Pearson, T., \& Van Sanford, D. (2019). Methods of Assessing Fusarium Damage to Wheat Kernels. Al-Qadisiyah Journal For Agriculture Sciences (QJAS)(P-ISSN: 2077-5822, E-ISSN: 26171479), 9(2), 297-308. https://doi.org/10.33794/qjas.Vol9.Iss2.91

Khaeim, H. M., Jeber, B. A., \& Ali, M. A. (2019). Winter Wheat Genotypes Response to Different Water Quality. Int. J. Agricult. Stat. Sci., 15(2), 669-676.

Kuo, S., Sainju, U. M, \& Jellum, E. J. (1997). Winter Cover Crop Effects On Soil Organic Carbon And $\begin{array}{lllllllll}\text { Carbohydrate In Soil. Soil Sci. Sm. } & \text { Soc. }\end{array}$ https://doi.org/10.2136/sssaj1997.03615995006100010022x

Lakshmana, M. (2000). Azotobacter Inoculation And Crop Productivity In Azotobacter In Sustainable Agriculture: Ch. 11 (Ed.) Neeru Narula, India.

Lugtenberg, B. (2006). Interactions In The Rhizosphere, Programs And Abstract Book, 7th International Workshop On Plant Growth Promoting Rhizobacteria Noodwijker Hout, The Netherlands. Lutgtenberg, Rubin. Leiden Univ.

Makinde, E. A., Ayeni, L. S., Jenny, S. O., \& Odedina, J. N. (2010).Effect Of Organic, Organomineral, And NPK Fertilizer On Nutritional Quality Of Amaranthus In Lagos, Nigeria. Researcher, 2(2), 91-96.

Mittal, V., Singh, O., Nayyar, H., Kaur, J., \& Tewari, R. (2008). Stimulatory Effect Of Phosphate Solubilizing Fungal Strains. (Aspergillus Awamori And Penicillium citrinum) on the Yield of Chickpea (Cicer Arietinum L.C.V. O. PF2) Soil Biochem, 40, 718-727. https://doi.org/10.1016/j.soilbio.2007.10.008

Nelson, E. B. (2004). Microbial Dynamics And Interaction In The Spermosphere. Annual Review of Phytopathology, 42, 271-309. https://doi.org/10.1146/annurev.phyto.42.121603.131041

Okabe, S., Nakamura, Y., \& Satoh, H. (2012). Community Structure And In Situ Activity Of Nitrifying Bacteria In Phragmites Root-Associated Biofilms. Microbes Environ, 27(3), 242-249. https://doi.org/10.1264/jsme2.ME11314

Perucci, P., Gliusquiani, P. L., \& Scaroni, L. (1982). Nitrogen losses from added urea and urease activity of a clay -loam soil amended with crop residues. Plant and Soil, 69, 457-463. https://doi.org/10.1007/BF02372466

Pinton, R., Varanini, Z., \& Nannipieri, P. (2001). The Rhizosphere As A Site Of Biochemical Interaction Among Soil Components, Plants, And Microorganisms. In: The Rhizosphere: Biochemistry And Organic Substances At The Soil - Plant Interface. Pinton, R.; Z. Varanini And P. Nannipieri,(Eds.), Marcel Dekker, New York. Pp: 
$1-17$.

Sahrawat, K. L. (1983). Relationship between soil urease activity and other properties of some tropical wetland rice soils. Fertilizer Research, 4, 145-150. https://doi.org/10.1007/BF01053251

Selim, E. M., Al-Neklawy, A. S., \& Mosa, A. A. (2010). Humic Acid Fertigation of Drip Irrigated Cowpea Under Sandy Soil Condition.American. Eurasian J.Agric\& Environ. Sci., 8(5), 538-543.

Shulka, G., \& Varma, A. (2011). Soil Enzymology, Soil Biology 22.DOI, Springer-Verlag Berlin Heidelberg. https://doi.org/10.1007/978-3-642-14225-3

Sinsabaugh, R. L., Antibus, R. K., \& Linkins, A. E. (1991). An Enzymic Approach to the Analysis of Microbial Activity During Plant Litter Decomposition. Agric Ecosyst Environ, 34, 43-54. https://doi.org/10.1016/01678809(91)90092-C

Sinsabaugh, R. L., Gallo, M. E., Lauber, C., Waldrop, M. P., \& Zak, D. R. (2005). Extracellular Enzyme Activities And Soil Organic Matter Dynamics For Northern Hardwood Forests Receiving Simulated Nitrogen Deposition. Biogeochemistry, 75, 201-215. https://doi.org/10.1007/s10533-004-7112-1

Sparling, G. P. (1992). Ratio Of Microbial Biomass Carbon To Soil Organic Carbon As A Sensitive Indicator Of Changes In Soil Organic Matter. Aust J Soil Res., 30, 195-207. https://doi.org/10.1071/SR9920195

Tabatabi, M. A., \& Bremner, J. M. (1972). Assay of urease activity in soils. Soil. Biol. Biochem., 4, 479-487. https://doi.org/10.1016/0038-0717(72)90064-8

Tietjen, T., \& Wetzel, R. G. (2003). Extracellular Enzyme-Clay Mineral Complexes: Enzyme Adsorption, Alteration Of Enzymeactivity, And Protection From Photodegradation. Aquat. Ecol., 37(4), 331-339. https://doi.org/10.1023/B:AECO.0000007044.52801.6b

Vessey, J. K. (2003). Plant Growth Promoting Rhizobacteria As Biofertilizers. Plant And Soil, 255(2), 571-586. https://doi.org/10.1023/A:1026037216893

Wallenstein, M. E., Michael, N. W., \& Zoppini, A. (2013). Soil Enzymes In A Changing Environment: Current Knowledge And Future Directions. Soil Biol Biochem, 58, 216-234. https://doi.org/10.1016/j.soilbio.2012.11.009

Yassin, M. F., Mahmoud, H. M. \& Khamis, A. J. (2010). The Role of Organic Waste in Reducing the Effect of Salt Water on Some Chemical Soil and Readiness of N, P, and K. Iraqi Agricultural Science Journal, 41(1), 133141.

Yoshimune. (2010). Crystal Structure of Salt-Tolerant Glutaminase From Micrococcus Luteus K-3 in the Presence and Absence of its Product L-Glutamate and its Activator Tris. FEBS Journal, 277(3), 738-748. https://doi.org/10.1111/j.1742-4658.2009.07523.x

\section{Copyrights}

Copyright for this article is retained by the author(s), with first publication rights granted to the journal.

This is an open-access article distributed under the terms and conditions of the Creative Commons Attribution license (http://creativecommons.org/licenses/by/4.0/). 